\title{
THE DISTRIBUTION OF CORPORATE DIVIDENDS
}

\section{Alexander Hamilton Frey $\dagger$}

Of primary importance to the investor in corporate shares is the dividend return. But many a purchaser of shares has other dominant interests. He may desire merely to qualify to be a director. He may be a "pirate" and contemplate a particular suit which he can institute only as a shareholder. He may hope to acquire the right of a shareholder to examine the stock ledger or other books or records of the corporation in order to broaden his activities as a broker or promoter. He may seek to gain control of the corporation in order to loot it, or to preclude it from competing with some other enterprise in which he is primarily interested. He may be a speculator buying shares to cover a previous "short" sale, or in anticipation of a rising market and a profitable resale. No one of these persons has the interest of an investor. The investor buys shares for the long pull, and while he will be gratified by an appreciation in market value, his major concern is with income, i. e. dividends.

One investing in corporate shares, whether an individual or an institution, desires the corporation to make the maximum possible profits and to distribute such profits in the form of dividends as rapidly as may be consistent with the continuation of maximum profits in the future. But this may not be the goal of the corporation's management. In many modern corporations the ownership of the shares is so widely scattered that the management, $i$. e. executive officers and directors, through control of the proxy process for shareholders' meetings, is self-perpetuating. ${ }^{1}$ Where such management control exists, the members of the management may own very few shares, as personal shareholdership is not the basis of their control. And where the officers and directors themselves own very few shares, their interest in the corporation may relate primarily to matters other than the distribution of profits. They may develop philanthropic interests such as raising living standards by increasing wages as rapidly as competitive conditions allow, or by progressively producing more and cheaper units to the benefit of the consuming public. Or they may be interested not in dis-

† A.B., I919, Yale University; M. A., 1920 Columbia University; IL. B., I921, J. S. D., 1925, Yale University Law School ; 1921-23, University of Oxford; Professor of Law, University of Pennsylvania Law School; Advisor, RESTATEMENT, BUSINESS Assoctations and Restatement, Sectrities; author, Cases and Statutes on BustNESS Associatioss (1935); Modern Dezclopment in the Law of Pre-incorporation Subscriptions (193I) 79 U. of PA. L. REv: 1005; Some Thoughts on Law Traching and the Social Scicuces (1934) 82 U. of PA. L. Rev. 463; The National Labor Relations Act Should Not Be Ancuded at the Present Session of Congress (1939) 33 ILL. L. REv. 668; contributor to various other legal periodicals.

I. See Berle and Mfenss, The afoders Corporation asd Private Property (1933) 84 ct scq. 
tributing profits, but in ploughing them back into the enterprise in order to magnify the size of the business and thereby improve their own power and prestige or strengthen their claim to huge salaries and bonuses.

Where such a conflict of interests between management and shareholders exists, the law has developed in such a way as to favor management. In two important respects management may legally exercise a very high degree of discretion. First, management is permitted flexibility in the application of accounting practices so that it can affect the size of the surplus or net earnings available for dividends. ${ }^{2}$ For example, it may elect to write off items such as depreciation or obsolescence at a slow or at a rapid rate; it may elect to regard expenditures on new equipment as operating expenses or as deferred assets; it may carry good will at zero or at a substantial figure. While it is not the purpose of this article to examine the legal and accounting principles for ascertaining the fund from which dividends may be paid, ${ }^{3}$ but only to consider conflicting claims to the distribution of such fund, it is important to note that in the matters indicated above, as well as in many others, discretionary decisions of management will seriously affect the size and even the very existence of the fund available for dividends. The manner in which this discretion is exercised may be of extreme importance to the holders of certain classes of shares, e. g. non-cumulative preferred shares, whose rights to specific dividends may depend, at least in some jurisdictions, upon whether or not there were undistributed profits in the past."

Secondly, even after it has been established that there are net earnings available for dividends, management is given almost unlimited discretion as to whether the fund shall be distributed to the shareholders or retained in the enterprise. ${ }^{.}$. This discretion is not confined to divi-

2. See Graham and Katz, Accounting in Laiv Practice (1932) chs. 19 and 20 ; Hills, Accounting in Corporation L.lw (r937); Berle and Fisher, Elcments of the Laiv of Business Accounting (1932) 32 CoL. L. REv. 573; Bonbright and Weiner, Theory of Anglo-American Dividcud Law: Surplus and Profits (1930) 30 CoL. L. Rev. 330, 354

3. See Katz, Accounting Problcms in Corporate Distributions (194I) $89 \mathrm{U}$. of $P A$. L. REv. 764 , infra in this issue.

4. See infra at 750 et seg.

5. Wabash R. R. v. American Refrigerator Transit Co., 7 F. (2d) 335, 342 (C. C. A. 8th, 1925): W. Q. O'Neall Co. v. O'Neall, 25 N. E. (2d) 656 (Ind. App. 1940); Schmitt v. Eagle Roller Mill Co., 199 Minn. 382, 272 N. W. 277 (1937); Shonnard v. Elevator Supplies Co., III N. J. Eq. 94, 161 Atl. 681 (I932); City Bank Farmersi Trust Co. v. Hewitt Realty Co., 257 N. Y. 62, 177 N. E. 309 (1931); Green v. Philadelphia Inquirer Co., $329 \mathrm{~Pa}$. 169,196 At1. 32 (1938); Jones v. Motor Sales Co. of Johnstown, 322 Pa. 492, I85 Atl. 809 (1936) ; Ballantine, Manual of Corporation LAW AND PRACTICE (1930) § I57; II FLETCHFR, CyCLOPEDIA OF CoRPORATIONS (1932) 802; STFIENS, PRIVATE CoRporations (1936) §99. For instances of limitations upon the directors' discretion see In re Brantman, 244 Fed. Ior (C. C. A. 2d, 1917); Channon v. Channon Co., 218 Ill. App. 397 (1920); Dodge v. Ford Motor Co., 204 Mich. 459, I70 N. IV. 668 (1919); Seitz v. Union Brass and Metal Mifg. Co., 152 Minn 460, 189 N. W. 586 (1922); and Lawton v. Bedell, 7I Atl. 490 (N. J. Eq. 1908). 
dends on common shares; it extends as well to dividends on all types of preferred shares. ${ }^{\circ}$ Consequently, if the interest of management lies in expanding the wealth under its control, profits may for years be hidden or, where revealed. ploughed back into the corporation. And as the saturation point for expansion approaches, the profits, if any, on the reinvested earnings may be disproportionately small to the longterm detriment of the shareholders. Almost complete discretion in the managers as to when to declare a dividend is a salutary rule so long as the managers are themselves substantial sharcholders and chosen by majority vote, conditions prevailing during the development of the rule. But when, as in many gigantic modern corporations, the managers own few shares and are self-perpetuating, ${ }^{7}$ the rule ceases to be merely a method of preventing a rapacious minority from forcing the directors to make ill-advised distributions of corporate assets. It becomes a device for building up economic empires for the manngers by forcing the shareholders continually to increase their investment in return for, at most, additional pieces of paper euphemistically called "stock" dividends.

Some states, seeking to curtail this common law discretion of corporate managers as to distributing or withholding profits, have enacted legislation entitling the shareholders to receive the net earnings of the corporation annually, after there has been set aside such a sum as the shareholders may in good faith determine shall be retained as accumulated surplus. ${ }^{8}$ The desirability of such laws is debatable. To the extent that they put an end to uneconomic corporate "hoarding" and to new pyramids of power on the part of management, they are commendable. But to the extent that they prevent the development of adequate reserves with which to cushion periods of unavoidable adversity." or preclude self-financing of sound expansion projects, they are of doubtful merit. A better solution would be to authorize the courts (or preferably an administrative body), upon petition of an intercsted shareholder, to order the annual distribution of net earnings unless management could sustain the burden of justifying the retention in the enterprise of all or part thereof.

The common law discretion of the management, however, may be replaced, under certain circumstances, by a duty to declare dividends, if earned. Such a duty may be iniposed not only by legislative enactment but also by specific provision in the corporate charter or even by

6. Morse v. Boston \& Maine R. R., 263 Mass. 308, 160 N. E. 894 (1928).

7. See note I supra.

8. N. M. STAt. ANn. (Courtright, 1929) §32-156; N. C. Cone ANs. (Michie, 1935) § 1178; LAws OF PORTo Rico (1916) No. 24, \$9. A tax on undistributed corporate surplus is another device for inducing a more liberal dividend policy on the part of management. 
contract. $^{8}$ But when the language relied upon as creating the duty requires interpretation, the courts are not strongly inclined to construe the duty into existence. ${ }^{10}$ Even where a corporation purports to "guarantee" the payment of stipulated dividends, some courts have declined to compel the distribution of available profits to the holders of such "guaranteed" shares. ${ }^{11}$ It is well settled, however, that if the directors do declare a dividend of available profits and this fact is communicated to the shareholders, the distribution of this sum to the shareholders can be compelled $;^{12}$ the directors' own conduct results in duty replacing discretion.

So long as a given corporation has but one class, i. e. common shares, outstanding, the fact that the retaining or distributing of profits lies within the discretion of management may cause little permanent harm to those who have invested in such shares; if all goes well, they will ultimately receive the profits in one form or another. But if the corporation has two or more classes of shares outstanding, with varying rights to dividends incident to each, the manner in which management exercises its discretion as to dividend payments may permanently favor one class of shareholders at the expense of another. In such instances the fact that management's dividend policy may not have been motivated by special consideration for one class of shareholders will not render the harm to another class any the less acute. It is with this

9. Burk v. Ottawa Gas \& Electric Co., 87 Kan. 6, 123 Pac. 857 (1912) ; Lydia E. Pinkham Medicine Co. v. Gove, 20 N. E. (2d) 482 (Mass. 1939); Spear v. RocklandRockport Lime Co., I13 Me. 285, 93 Atl. 754 (1915); Park v. Grant Locomotive Works, 40 N. J. Eq. 114, 3 Atl. IG2 (1885); II FLETCHER, op. cit. supra note 5 at 805. 10. New York, Lake Erie \& Western R. R. v. Nickals, IIg U. S. 296 ( 1886 ).

11. Smith v. Southern Foundry Co., $166 \mathrm{Ky} .208,179$ S. W. 205 (1915); Kidd v. Puritana Cereal Foods Co., 145 Mo. App. 502, 122 S. W. 784 (1909); Castorland Milk and Cheese Co. v. Shantz, 179 N. Y. Supp. I31 (1919). Contra: Cratty v. Peoria Law Library Ass'n, 219 III. 516,76 N. E. 707 (1906).

12. Maloney v. Western Cooperage Co., 103 F. (2d) 992 (C. C. A. 9th, 1939); Flynn v. Haas Bros., 20 F. (2d) 510 (C. C. A. 9th, 1927); Smith v. Taecker, ${ }^{133}$ Cal. App. 351, 24 P. (2d) 182 (1933) Bcers v. Bridgeport Spring Co.. 42 Conn. 17 (1875); Quinn v. Quinn Mfg. Co., 201 Mich. 664,167 N. W. 898 (1918); Northwestern Marble \& Tile Co.v. Carlson, 116 Minn. 438, 133 N. W. Iol4 (1912); ArcLaren v. Crescent Planing Mill Co., 117 Mo. App. 40, 93 S. W. 819 (1906); Billingham v. Gleason Mffg. Co., Iol App. Div. 476, g1 N. Y. Supp. 1046 (1905), aff'd, 185 N. Y. 571,78 N. E. 1099 (1906), II: re Given's Estate, 323 Pa. 456, 185 Ati. 778 (1936); BALLANTINE op. cit. supra note 5 at 503; I I FLETCHER, op. cit. sipra note 5 at $\$ 5322$; STEVENS, op. cit. supra note 5 at 399. See Note, Declaration of Diridends-Stockholdcrs as Crcditors (1930) $28 \mathrm{MfICH}$. L. Rev. 914.

Several text writers state that a share dividend in contra-distinction to a cash dividend may be effectively revoked; in support of this contention only two cases are cited, neither of which is persuasive, wamely, Terry v. Eagle Lock Co., 47 Conn. 14r (1879) and Staats v. Biograph Co., 236 Fed. 454 (C. C. A. 2d, 1916). On the other hand, in the case of Dock v. Schlichter Jute Co., I67 Pa. 370. 31 Atl. 370 (1895), it was held that an attempted revocation of a declaration of a dividend of the corporations's oun shares, which it had previously created and thereafter received in payment of a debt owed to it, was no defense to an action by a shareholder for his proportion of the dividend. For an extended discussion of these cases and the underlying problem see Frey, Is a Declaration of Subsiripfion "Rights" Rctocable? (1930) 39 Y ALE L. J. II63. See also Note, Declaration and Rescission of Cash and Stock Diaidends (1916) 16 CoL. L. RFx: 599. 
competition for profits between shareholders having divergent rights to dividends that this article is particularly concerned.

Corporations seldom declare dividends of all of the net earnings of a given fiscal period immediately upon the termination of such period. If there has been a past omission to distribute profits, this factor may affect the respective rights of shareholders of various classes to dividends subsequently declared. On the other hand, many important dividend disputes are unrelated to any accumulation of earnings in bygone years. In considering the conflicts between shareholders over dividends, this article will segregate these two situations. Those problems which may arise whether or not profits of earlier years have been undistributed will be dealt with first; and with this analysis as a background, the remainder of the paper will be devoted to an inquiry into the extent to which the fact that certain past profits were not distributed as earned may affect the subsequent rights of shareholders when dividends are thereafter declared.

\section{The Dividend Incidents of Various Types of Shares}

The existence of a dividend preference is always a matter of specific provision in the articles of association. Unfortunately, however, not infrequently the corporate articles omit to specify whether the holders of the preferred shares are to be limited to the amount of the preference or to be entitled to participate beyond the amount of the preference if the corporate earnings warrant. Moreover, similar defective draftsmanship may give rise to a dispute as to whether the preference is cumulative or not, i. e. if the amount of the preference is not received in a given year because not earned, does a right to this amount carry over into succeeding years?

If, as all too frequently happens, a corporation's articles do not unequivocally set forth the exact rights of the holders of each of its authorized classes of shares, controversies such as those just indicated are inevitable. Conflict between classes of shareholders over dividend payments usually relate to matters which the parties, i. e. the promoters, incorporators, or subscribers, or the directors, officers, shareholders or underwriters, or their respective attorneys, did not anticipate. Consequently, the problem is not to ascertain the non-existent "intent" of the parties, but to determine what reasonable persons would have intended, if the problem had been initially raised, in view of the circumstances existing at the time of the creation of the shares.

The normal process whereby a corporation seeks to assemble funds, other than by borrowing, is by the creation of voting common shares, i. e. shares unpreferred and unlimited both as to dividend payments and 
capital distributions. When a corporation offers for subscription shares having different attributes, there is always some underlying reason, usually to be found in a relation between the condition of the corporation and the state of the prevailing money market. ${ }^{13}$ If the corporation is earning only three percent on its capital and if this is low in relation to prevailing money rates, the corporation will have to offer special inducements to attract new capital from prospective shareholders. Such conditions may result in the offering of fully participating, preferred shares, i. e. shares which are on a parity with common as far as the extent of dividend participation is concerned and which also have a first claim on dividend distributions up to a stated amount. If, on the other hand, the corporation is earning a return on its capital which is high in relation to prevailing money rates, it can acquire such new funds as it may seek in one of several ways: by borrowing money at low interest rates; or by offering additional common shares to its existing shareholders at less than market value; or by offering additional common shares, probably non-voting, to the public at their market value, which in the case of par value of shares would be at a premium; or by offering to the public a new class of shares having an aggregate of incidents deemed to be inferior to those of common shares at the price asked. For example, such a corporation might offer at $\$ 100$ per share, nonvoting shares of $\$ 100$ par value, having a non-cumulative, $6 \%$ preference as to dividends and being limited thereto, and being subject to redemption at par at the option of the corporation on and after a stipulated date. The average investor in this type of share may prefer it to a bond because of a higher yield; he may prefer it to an open market purchase of common shares of the corporation because of the lower price and the greater security in the event of an adverse turn in the corporation's fortunes; and yet at the same price, i. e. \$100 per share, he might prefer a common share in the corporation because of its greater income potentialities.

Whenever there are preferred shares outstanding there must also be common, for the preferred shareholders cannot be preferred without someone over whom to be preferred; nor can shareholders be limited as to dividends unless there are others who are entitled unlimitedly to participate in further distributions of profits. It cannot be too strongly emphasized that when disputes over dividend distributions arise between shareholders of various classes (or even between shareholders of the same class), the only rational basis for resolving such disputes is by reference to the conditions present and prospective that induced the

13. Dewixg, Fisancial Policy of Corporations (3d ed. i934) 43-67, 302-31t, $1040-1067$. 
offer and the acceptance of those shares which are junior in time to the other shares involved in the dispute.

Actually, in the opinions dealing with the question as to whether preferred shares are participating or non-participating, cumulative or not, one finds very little reference to the conditions which resulted in the particular preferred issue. And yet the general attitude of the courts in these cases indicates that such considerations might be given great weight if adequately presented by counsel, for the courts emphasize that the problem is primarily one of interpreting the contract of the parties. For example, with reference to the matter of participation, some courts, a majority, say that the preference must have been intended in lieu of all further participation and that therefore the preferred are limited thereto as a maximum. ${ }^{14}$ Other courts, a minority, conclude that the parties must have intended all shares to have the same incidents except in so far as specific differences are enumerated and that therefore the preferred are, on a parity in this respect with common, unlimited as to dividends. ${ }^{15}$ The financial circumstances accompanying the issue ought to shed important light on this question of what the parties would have intended if they had anticipated the problem.

With almost complete unanimity the courts have held that, where the articles are silent, preferred shares are cumulative. ${ }^{16}$ The underlying thought seems to be that if the common shareholders concede that another class is to have a stipulated preference as to dividends, the common are in effect agreeing that the fund thereafter available for dividends shall not be diminished by dividends to themselves, until the preferred have received the amount of their preference for each year of their existence. And this conclusion will be reached, whether the prob-

14. Niles v. Ludlow Valve Mffg. Co., 202 Fed. I4I (C. C. A. 2d, 19r3); Tennant v. Epstein, 356 Ill. 26, 189 N. E. 864 (1934); Stone v. U. S. Envelope Co., 119 Me 394, III Atl. 536 (1920); James F. Powers Foundry Co. v. Mfiller, 166 M1d 590, I7I AtL 842 (I934); Scott v. Baltimore \& Ohio R. R., 93 MId. 475, 49 Atl. 327 (I90I); Murphy v. Richardson Dry Goods Co., 326 M1o. 1, 31 S. WV. (2d) 72 (1930); Duwelius v. Champion Fibre Co., 25 Ohio N. P. (N. S.) 107 (Ig24); Shimmon v. Nat'l Screw and Tack Co., 18 Ohio N. P. (N. S.) 569 (1916). See Harno, Rights of Common and Preferred Stockholders to Share in Surplus (1925) 20 ILI L. REv. 288.

15. Englander v. Osborne, 26I Pa. 366, 104 Atl. 614 (1918); Sterling v. Watson, $241 \mathrm{~Pa}$ 105, 88 Atl. 297 (1913); Sternberg v. Brock, 225 Pa. 279, 74 Atl. II6 (1909); Fidelity Trust Co. v. Lehigh Valley R. R., $215 \mathrm{~Pa}$. 610, 84 Atl. 829 (I906). See also Lyman v. Southern R. R., I49 Va. 274, I4I S. E. 240 (1928). See Note, Conflicting Clains of Preferred and Common Shareholders With Respect to Corporate "Profits" (I93I) 79 U. OF PA. L. REv. 466.

16. Hazel Atlas Glass Co. v. Van Dyk \& Reeves, Inc., 8 F. (2d) 716, 720 (C. C. A. 2d, 1925); Warburton v. John Wanamaker, Philadelphia, $329 \mathrm{~Pa} .5,196$ Atl. 506 (1938); Fidelity Trust Co. v. Lehigh Valley R. R. Co., $215 \mathrm{~Pa} .610,64$ Atl. 829 (I906) ; BALLANTINE, op. cit. sipra note 5 at 528 ; I2 FLETCHER, op. cit. sipra note 5 at I88. Contra: Elkins v. Camden, etc, R. R., 36 N. J. Eq. 233 (I882). A "guarantee" of dividends on preferred shares has uniformly been held to have the effect of making the dividend preference cumulative. Lockhart v. Van Alstyne, 31 Mfich. 76 (1875); Boardman v. Lake Shore, etc., R. R., 84 N. Y. 157 (188I); Prouty v. Mfichigan, etc, R. R. Co., I Hun (N. Y.) 655 (1874). 
lem arises while the corporation is a going concern or when it is in process of liquidation. ${ }^{17}$

Incidentally, it is interesting to note that if preferred shares are cumulative, either as a result of express stipulation or judicial construction, the courts are strongly inclined to protect the interests of such shareholders in accumulated, unpaid, back dividends. For example, where such shares are eliminated by a statutory reduction of capital stock, a right to the amount of the back dividends has been held nevertheless to survive. ${ }^{18}$ And where attempts have been made to wipe out rights to accrued dividends by amending the articles, the courts have been more alert to invalidate such amendments than any others affecting the incidents of a particular class of shares. ${ }^{19}$ On final dissolution of a corporation, the common shareholders have at times contended that the right to accrued back dividends on cumulative preferred shares is gone, either on the theory that the right is a right to dividends and that dividends can be paid only by a going concern and not by one in the process of liquidation, or that there is no surplus and the right is merely to receive a preference in the distribution of profits. But here, too, the courts have favored the holders of the cumulative shares, and the majority have held that such shareholders are entitled to the amount

17. Fawkes v. Farm Lands Inv. Co., 112 Cal. App. 374, 297 Pac. 47 (193I); Pennsylvania Co. v. Cox, I99 At1. 67I (Del. Ch. I938); Garrett v. Edge Moor fron Co., 194 Atl. 15 (Del. Ch. 1937); Pennington v. Commonwealth Hotel Construction Corp., I7 Del. Ch. 394, I55 Atl. 514 (I93I) ; Johnson v. Johnson \& Briggs, I38 Va. 487 122 S. E. 100 (1924); Drewry-Hughes Co. v. Throckmorton, I20 Va. 859, 92 S. E 818 (I917) ; cf. to the same effect, Wilson v. Laconia Car Co., 275 Mass. $435,176 \mathrm{~N}$. E 775 (1931). Contra: Michael v. Cagey-Caguas Tobacco Co., 190 App. Div. 618, 180 N. Y. Supp. 532 (1920); Powell v. Craddock-Terry Co., 175 Va. 146, 7 S. E. (2d) 143 (I940).

18. Roberts v. Roberts-Wicks Co., 184 N. Y. 257, 77 N. E. 13 (1906).

19. Bay Newfoundland Co., Ltd. v. Wilson \& Co., 4 A. (2d) 668 (Del. Ch. 1939); Consolidated Film Industries v. Johnson, 197 Atl. 489 (Del. 1937); Keller v. Wilson \& Co., 190 Atl. Ir 5 (Del. 1936); Aforris v. American Public Utilities Co, I4 Del. Ch. 136, 122 At1. 696 (1923); Lonsdale Securities Corp. v. International Mercantile Marine Co., 101 N. J. Eq. 554, 139 Atl. 50 (1927) ; Patterson v. Durham Hosiery Mills, 214 N. C. 806,200 S. E. 906 (1939); Harbine v. Dayton Malleable Iron Co., 61 Ohio App. I, 22 N. E. (2d) $28 \mathrm{I}$ (1939). See, to the same effect, as to consolidation, Colgate v. U. S. Leather Co., 73 N. J. Eq. 72,62 Atl. 657 (1907), res'd on other grounds, 75 N. J. Eq. 229, 72 Atl. 126 ( 1909 ). That the shareholder's right may be lost through laches, see Frank v. Wilson \& Co., 9 A. (2d) 82 (Del. Ch. I939) ; Romer v. Porcelain Products, 2 A. (2d) 75 (Del. Ch. 1938). Conira: Harr v. Pioneer Mechanical Corp., 65 F. (2d) 332 (C. C. A. 2d, 1933), cert. denied, 290 U. S. 673 (1933); McGuillen v. National Cash Register Co., 27 F. Supp. 639 (D. Md. 1939). See, to the same effect, as to a merger, Federal United Corp. v. Havender, II A. (2d) 331 (Del. I940).

It has been held that, at a time when there are accumulated unpaid dividends on a given class of preferred shares, the corporation may create a new class of prior preferred shares (without cancelling the old preferred or their accrued dividends) and may thereafter pay dividends on the new preferred before paying the back dividends on the old, cumulative preferred, at least if the dividends on the new preferred are limited to subsequent earnings and do not come out of past surplus: Blumenthal $y$. Di Giorgio Fruit Corp., 30 Cal. App. (2d) II, 85 P. (2d) 580 (1938); Shanik v. White Sewing Machine Corp., 15 A. (2d) 169 (Del. Ch. 1940); Thomas v. Laconia Car Co., 251 Mass. 529, $146 \mathrm{~N}$. E. 775 (1925); Johnson v. Lamprecht, 133 Ohio $567,15 \mathrm{~N}$. E. (2d) 127 (1938); Yoakam v. Providence Biltmore Hotel Co., 34 F. (2d) 533 (D. C. R. 1. 1929). See also Note (I94I) 89 U. of PA. L. REv. 789, infra, in this issue. 
of the accumulated dividends, dissolution or no dissolution, before the common receive anything, even if this sum has to come out of the capital which the common originally contributed to the enterprise. ${ }^{20}$

Some of the cases referred to in the preceding paragraph reflect a strange notion that crops up from time to time even with respect to corporations that are active, going concerns, viz. that increases in the amount of the nct assets, not resulting from payment for shares, may be realized and yet not be available for dividend purposes, despite the absence of any previous capital impairment. This delusion may result from familiarity with certain phases of English corporation law. There the term "capital" is by some used not to refer to a figure indicating the amount (loosely speaking) which the shareholders have stibscribed for their shares, but to the land or other property which the corporation acquires with such sum; ${ }^{21}$ and if the land or other "capital" appreciates in value, this is regarded as a "capital" increase and subject to eventual distribution in accordance with the rules for distributing "capital". Hence, in England, it makes some sense to indicate that a share, preferred as to capital, may be either limited to the amount of the preference or entitled to further participation in capital distributions. But in the United States the prevailing doctrine is that all of the net assets, in excess of the amount of the shareholders' subscriptions allocated to capital, are profits, and as such subject upon eventual distribution to the rules relating to dividends. ${ }^{22}$ Where not modified by statute, this is true even as to paid-in (or "capital") surplus. ${ }^{28}$ And the same rules should operate whether the fund is distributed during the life of the corporation or upon final liquidation.

Consider this illustration. Corporation $C$ issues 1,000 common shares, and 1,000 shares preferred as to dividends to the extent of $\$ 6$ per share and limited thereto, but in other respects on a parity with the common. For each share Corporation $C$ receives $\$ 100$, the par value. Of the $\$ 200,000$ thus received, Corporation $C$ invests $\$ 100,000$ in real property. During its first fiscal year ( $I$ ) the corporation has net earnings from operations of $\$ 10,000,(2)$ it receives a gift of $\$ 10,000$, and (3) the directors sell a portion of the corporation's real property in excess of its needs for a profit of $\$ 20,000$. If at the end of the year the directors were to declare a dividend of $\$ 6$ per share on the preferred

20. The cases are set forth in note 16 supra.

21. Ammonia Soda Co. v. Chamberlain [Igr8] I Ch. 266; Verner v. General \& Comm'l Investment Trust [1894] 2 Ch. 239, 265. See Reiter, Profits, Dividends ANd THE LAW (1926) 7I-72.

22. II Fletchep, Cyctopedia of Corporations (1932) \& 5335.

23. Benas v. Title Guaranty Trust Co., $216 \mathrm{Mo}$. App. 53, 267 S. W. 28 (1924): Equitable Life Assurance Society v. Union Pacific R. R., 212 N. Y. 360 , 106 N. E. 92 (1914); Note, Declaration of Dividend's from Paid-in Surplus (193I) 31 CoL L. REv. 844; RerTrR, op. cit. supra n. 21, c. XIX. But see Merchants' \& Insurers' Reporting Co. v. Schroeder, 39 Cal. App. 226, 178 Pac. 540 (1918). 
and $\$ 34$ per share on the common, no right of the preferred would be violated. In short, despite the fact that the preferred are identical with the common except for the preference and limitation as to dividends, everything that the corporation gains beyond the dividend requirements on the preferred belongs to the common whether it be earned from the conduct of the enterprise, or derived from unearned appreciation in asset values, from gifts, etc. And, as will be more fully developed later in this paper, ${ }^{24}$ the fact that such gains are permitted to accumulate ought not adversely to affect the right of the common to receive the amount in question whenever distributed, whether this be during the life of the corporation or upon dissolution.

\section{The Effect of Date of Issue Upon Dividend Claims}

Within a single class of shares, each share normally entitles the holder to an equal proportion of the profits, even though the shares may have been created at different times. ${ }^{25}$ Let us suppose that Corporation $C$ is formed with an authorized capital stock of 2,000 common shares of $\$ 100$ par value each and that at its inception it issues at par 1,000 of such shares. During the first year of its existence it has net earnings of $\$ 2,000$. At the end of this year it accepts public subscriptions to the remaining $I, 000$ authorized common shares. During the second year the net earnings are $\$ 4,000$. If at the end of the second year the directors were to declare a $\$ 3$ dividend on each of the 2,000 shares outstanding, the rights of the holders of the 1,000 shares first issued (if, indeed, they could all be identified) would not be violated despite the fact that one-third of the net earnings had occurred during a period when they were the sole shareholders. The reason is that the law assumes, in the absence of a showing to the contrary, that when the second $I, 000$ shares was issued to outsiders, the best price obtainable was received by the corporation. ${ }^{26}$ Since, in this hypothetical case, the corporation then had a surplus of $\$ 2$ a share, the new shares would normally be issued at a premium of substantially $\$ 2$ per share above par in order to equalize the interests of the old and the new shareholders in surplus; and if the corporation was not able to obtain such a premium, this would indicate that the financial market considered the old shareholders as having already lost some of their original investment. In other words, if the subscription price is adequate, the holder of each new share contributes to the corporate enterprise as much as the holder of each old share is deemed to have therein at that time, and if there

24. See infra at 750 et seq.

25. STEVENs, op. cit. sipra note 5 , at 511 .

26. The rule has been applied even to shares obtained by exercising a privilege of converting bonds into shares very shortly before the declaration of the dividend; see Jones v. Terre Haute \& Richmond R. R. Co., 57 N. Y. 196 (1874). 
is an existing surplus, this fact will be reflected in the price. If the subscription price is less than the market value, then the shares should be offered exclusively to the existing shareholders. ${ }^{27}$

If there are only common shares outstanding, and new common shares are offered proportionately to the present shareholders at par, although there is a then existing surplus, no injustice results as each shareholder has an opportunity to gain in book value on. his new shares just what he loses in book value on his old; and if a given shareholder elects not to subscribe to his proportion of the new shares, he can recover for his loss of surplus on his old shares by selling his rights to subscribe to the new shares. For example, if at a time when Corporation $C$ has outstanding 1,000 shares of $\$ 100$ par value each and a surplus of $\$ 50,000$ (i. e. $\$ 50$ per share), it creates another 1,000 shares at par, the surplus thereby becomes $\$ 25$ per share, old and new. Each old shareholder who exercises his right to subscribe proportionately to the new shares gains a $\$ 25$ interest in surplus on his new shares and loses a like interest on his old; and if he does not want more shares, he can normally compensate for the decrease in the amount of surplus to which his old shares will be entitled by selling his right to subscribe to the new shares for substantially that amount, thereby obtaining in cash the amount by which his right to future dividends has been diminished.

Although within a given class of shares the different dates of issue of various shares do not normally affect their respective rights to dividends, in the case of cumulative preferred shares dividend rights may be proportionate to the length of time that each of such shares has been outstanding. For example: Corporation C's authorized capital stock consists in part of 3,000 shares of $\$ 100$ par value each, having a cumulative preference as to dividends of $\$ 6$ per share. At its inception the corporation issues $I, 000$ of these shares at par. During the first year the corporation operates without profit or loss. At the end of the first year the corporation issues at par another $r, 000$ of these shares. During the second year the corporation again has no net earnings. At the end of the second year the corporation issues the third 1,000 of these shares at par. During the third year the corporation has net earnings of $\$ 30,000$, all of which the directors are willing to distribute among the holders of the cumulative preferred shares. How should this fund be divided? There are four plausible bases. First, each share should have the same dividend rights as every other share of this class, and, just as in the case of common shares, the duration of existence should be disregarded; ${ }^{28}$ under this theory each share would be

27. See Restatesiext, Business Associations (Tent. Draft No. r, 1928) $\$ 19$.

28. In Holland v. National Automotive Fibres, 194 Atl. 124 (Del. Ch. 1937), off'd, 2 Atl. (2d) 124 (Del. Ch. 1938), it was held that dividends on cumulative shares do not begin to accumulate until the date of issuance. 
allotted \$10. Second, the dividends accumulated on the first 1,000 shares being $\$ 18$ per share, on the second $1,000 \$ 12$ per share, and on the third $1,000 \$ 6$ per share, or $\$ 36,000$ in all, the holders of the first $1, \infty 00$ shares should get $18 / 36$ of the $\$ 30,000$, or $\$ 15$ per share, the holders of the second 1,000 shares $12 / 36$ or $\$$ ro per share, and the holder of the third 1,000 shares $6 / 38$ or $\$ 5$ per share. Third, the holders of the first 1,000 should get $\$ 6$ per share, or $\$ 6,000$, for the first year's dividends; the holders of the first 1,000 and of the second 1,000 should each get $\$ 6$ per share, or $\$ 12,000$, for the second year's dividends; this would leave $\$ 12,000$ out of the $\$ 30,000$ which should be divided equally for the third year among each of the 3,000 shares, i. e. $\$ 4$ per share; in this way each of the first $I, 000$ shares would receive $\$ 16$, each of the second $1,000, \$ 10$ and each of the third $\$ 1,000, \$ 4$. Fourth, the dividends having been earned during the third year, the dividends for that year should be paid first; this would require $\$ 6$ per share, or $\$ 18,000$; the dividends for the second year should next be paid; this would consume the remaining $\$ 12,000$, and would leave $\$ 6$ per share still owing on the first $1, \infty 00$ shares, with the other shares paid in full; or the remaining $\$ 12,000$ might be distributed $2 / 3$ to the holders of the first 1,000 shares and $1 / 3$ to the holders of the second 1,000 shares, in which event the first I,000 would receive $\$ 14$ per share, the second I,000, $\$ 10$ per share, and the third $\mathrm{I}, 000, \$ 6$ per share.

No court of record has apparently as yet been confronted with this problem, and there seems to be no "common understanding" 29 in the commercial world as to its solution. The second of the foregoing suggestions appeals to the present writer as the fairest, for it would seem reasonable to presume that the capital paid to the corporation by each group of shares has contributed to the eventual profits of the corporation in proportion to the length of time that the corporation has had the use of such capital. No surplus having been accumulated, it seems unlikely that the price obtainable for the later issues will be influenced in any way save downward by the fact that unpaid and unearned dividends have already accrued on other shares of the same class. Therefore the holders of the later shares cannot claim dividend parity with the earlier shareholders on the basis of any equalization increment in the subscription price paid by them.

In order to make it practical to keep track of the respective dividend claims of cumulative shares of a single class issued at varying times, each bluck of shares should when issued be earmarked as a designated series. Moreover, again in the interests of practicality, all such

29. See the expression of Mr. Justice Holmes in Wabash Ry. Co. v. Barclay, 280 U. S. 197,203 (1930). 
shares issued in a given fiscal year should be of the same series, and should entitle the holders thereof to the same dividend rights, despite the fact that the shares may have been outstanding for varying periods within the fiscal year.

A problem closely related to that last considered arises when a corporation issues two or more classes of cumulative preferred shares without designating either as prior to the other. For instance, the only difference between the two classes may be as to the amount of dividend preference; or one class may be voting, or participating as to dividends, or preferred as to capital, and the other not. In this event the shares should be treated as if they were merely various series of the same class, and the respective cumulative rights of each class should depend on the duration of its existence and the amount of its dividend preference. For example: Corporation $C$ at its inception issues $1, \infty 00$ common shares and $1,000 \$ 6$ cumulative preferred shares; there are no net earnings during the first year; at the beginning of the second year Corporation $C$ issues $\mathrm{I}, 000 \$ 8$ cumulative preferred shares; during the second year the net earnings are $\$ 15,000$, all of which the directors desire to distribute among the preferred shareholders. The dividends accumulated on the $\$ 6$ preferred being $\$ 12,000$, and on the $\$ 8$ preferred $\$ 8,000$, or $\$ 20,000$ in all, the holders of the $\$ 6$ preferred should get $12 / 20$ of the $\$ 15,000$, or $\$ 9$ per share, and the holders of the $\$ 8$ preferred should get $8 / 20$, or $\$ 6$ per share. This leaves unpaid back dividends or $\$ 3$ per share on the $\$ 6$ preferred and $\$ 2$ per share on the $\$ 8$ preferred, which must be added to future accruals in determining the respective rights of each class to subsequent net earnings.

But if, of two classes of preferred shares outstanding, one is cumulative and the other non-cumulative and neither is designated as prior, a different result should be reached. For example: Corporation $\mathrm{C}$ at its inception issues 1,000 common shares and $1,000 \$ 6$ non-cumulative preferred shares; at the beginning of the second year the corporation issues $1,000 \$ 6$ cumulative preferred shares; there are no net earnings during the first two years but during the third year the net earnings are $\$ 12,000$. If the basis previously suggested as to shares of a single class, or of more than one class all of which are cumulative, were to be adopted for the apportionment of this $\$ 12,000$, the result would be as follows: there having been no earnings during the first two years, the non-cumulative preferred have a "credit" of only $\$ 6,000$ for the third year; the cumulative preferred have a claim to $\$ 12,000$ for the two years of their existence; a total of $\$ 18,000$. So the non-cumulative would receive $\% / 18$ of the $\$ 12,000$, or $\$ 4$ per share, and the cumulative $12 / 18$ or $\$ 8$ per share. But during the second year of the corporation's existence 
there accrued in favor of the cumulative preferred a dividend right of $\$ 6, \infty 00$; this right ought to be accorded priority over any subsequent dividend credit that may develop with respect to non-cumulative preferred shares, i. e. shares of a different class. Hence $\$ 6,000$ of the $\$ 12,000$ should first be assigned to the back dividends on the cumulative preferred, and the remaining $\$ 6,000$ should be divided equally between them, leaving the cumulative preferred (but not the non-cumulative) with a claim of $\$ 3$ per share against future earnings.

If a corporation has outstanding two classes of shares, common shares and shares which have a dividend preference of $\$ 6$ per share and full participation thereafter, disputes may arise as to the extensiveness of the "participation" to which the holders of the preferred shares are entitled. It has been contended that, if the net earnings of a given fiscal year are to be distributed, the holder of each preferred share should first receive $\$ 6$ and should thereafter share equally with the holder of each common share in the remainder. But, in the absence of explicit language in the articles justifying a different result, the more general conclusion has been that the preference is no more than a first claim on the net earnings, and that therefore after the holder of each preferred share has received the full amount of his preference, the holder of each common share is entitled to a like amount, and then only are the remaining net assets subject to pro rata distribution between the common and the participating preferred. ${ }^{30}$

If there are two classes of participating preferred shares, e. g. $\$ 6$ and $\$ 7$, as well as common shares outstanding, to how much are the common shares entitled before the preferred shares begin to participate in any further distribution of net earnings? There is a general rule, subject however to various exceptions, ${ }^{31}$ to the effect that shares of all classes have similar attributes unless specific differences are set forth in the articles of association. If this rule be applied, the answer is not difficult. First the preferred shares would receive $\$ 6$ and $\$ 7$ respectively; then the common shares would be entitled to the balance of the net earnings up to $\$ 6$ per share; next the $\$ 6$ preferred and the common would each be entitled to an additional dollar per share if the net earn-

30. 12 FLETCHER, op. cit. supro n. 5, §5448; Bailey v. Hannibal, etc., R. R., 17 II all. 96 (U. S. 18,3). See Christ, Right of Holders of Preferred Stock to Participate in the Distribution of Profits (1929) 27 MfICE. L. REv. 731, 748.

31. E. g., where the articles are silent on the point, preferred shares are generally held to be cumulative (see note 16 stpra), but no element of dividend cumulation is incident to common shares; Englander v. Osborne, 26I Pa. 366, 104 Atl. 614 (1918); and Lockwood v. General Abrasive Co., 210 App. Div. 141, 205 N. Y. Supp. 511 (1924), aff'd, 240 N. Y. 592, 148 N. E. 719 (1925); also most courts hold that where the articles do not specify whether preferred shares may participate in dividends beyond the amount of the preference. such shares are limited to the designated preference (see note 14 supro), although there is no limit to the dividend participation of common shares. 
ings were sufficient; and finally any remaining net earnings would be subject to pro rata distribution between all three classes.

\section{Dividend Claims in a W'asting Assets Corporation}

Conflicts among preferred and common shareholders over dividends sometimes arise out of the fact that their corporation was formed to exploit a wasting asset, such as a patent. or a mine, or an oil well. The major asset of such a corporation is inevitably used up as a result of the conduct of the enterprise: the patent expires; the mine or the well is depleted. This fact has caused some courts to sanction a departure from the normal method of determining the fund available. for dividends. Such courts permit the profits or net earnings of these corporations to be calculated without any allowance for the annual depletion of the wasting asset in which the major part of the corporation's capital is invested.32 If the net earnings so calculated are periodically distributed to the shareholders in the form of dividends, a progressive capital impairment inevitably results. When the corporation has but one class of shareholders (necessarily common) and no funded debt, no great hardship may result from such a rule, especially if the shareholders are informed as to the portion of the dividends received that really represents a return of capital. But if the corporation has outstanding preferred shares as well as common, this variation from the normal accounting practice may be a distinct detriment to the preferred. $^{38}$ As the capital becomes impaired, the ability of the corporation to earn the amount of any dividend preference will progressively decrease. And if the preferred have a capital preference upon eventual liquidation, and are limited as to dividends to a designated amount, the progressive capital impairment resulting from the distribution to the common of the entire balance of the net earnings, so computed, will eventually cause the capital preference to be worthless, as there will be virtually nothing left upon dissolution out of which to honor the agreed capital preference. It is fatuous to argue that when persons subscribe for preferred shares in a wasting assets corporation, they impliedly agree that the nature of the enterprise warrants a disregard of depletion in determining the fund upon which the otherwise established dividend rules shall operate. The assets of all corporations are depleted-depreciate-through use. The very fact that the preferred shareholders have bargained for a preference as to dividends or

32. Mellon v. Mississippi Wire Glass Co., 77 N. J. Eq. 498, 78 Atl. 710 (1910); II FLETCHER, op. cit. supra note 5, § 5347.

33. Federal Mining \& Smelting Co. v. Wittenberg, 15 Del. Ch. 409, 138 Atl. 347 (1927); but see Wittenberg v. Federal Mining \& Smelting Co., I5 Del. Ch. 351, 138 AtI. 352 (1927). 
capital (or both) belies the notion that they have consented to distributions to the common shareholders which will either undermine or destroy their preference. For these reasons, if a wasting assets corporation has preferred shares outstanding, it should be required, in determining the fund available for dividends, to make the same allowances for depletion as if it were not a wasting assets enterprise. This is all the more true if the corporation was formed not to exploit a single specified property but to engage, for example, in a general mining business. In such case the corporation should keep its capital intact by accumulating cash or other assets so as to acquire other mining property when the original mine is exhausted. ${ }^{34}$

This concludes a consideration of the major disputes that may arise between shareholders when the management of their corporation elects to distribute by way of cash dividends the profits of a given fiscal period at the conclusion of that period. We turn now to the further complications which may arise when management, having elected to accumulate rather than distribute profits for a certain period, subsequently determines to declare a dividend.

\section{The Principle of Dividend Credit}

The author firmly believes that, in order to insure equitable treatment of all classes of shareholders, management should be required to abide by the following rule whenever a dividend is proposed subsequent to any prior omission to distribute profits of an earlier fiscal period: in the absence of an unequivocal provision of the applicable statutes, articles, by-laws or resolutions, the respective rights of the various classes of shareholders to the proposed dividend should be determined by reference to what their respective rights would have been to an amount equal to the fund about to be distributed, if all the profits of the corporation had been declared as dividends at the end of each fiscal period in which such profits were acquired.

While it is not believed that the application of this rule is limited to problems concerning non-cumulative preferred shares, it is of especial importance in relation to such shares. As to cumulative preferred shares, the law is clear: if the amount of the dividend preference for a given year is not paid, the right to receive this amount before the common receive any dividends is not gone but is carried over into subsequent years and added to the preferred rights arising in those years, and this accumulation results without regard to whether there have been past earnings out of which management might have elected to pay the preferred dividends or whether the past earnings have been

34 (1926) 40 HARv. L. REv. 318 
insufficient to meet the amount of the dividend preference. ${ }^{85}$ The statement that shares preferred as to dividends are non-cumulative at first blush suggests that with respect to the feature of cumulation they are the exact opposite of cumulative preferred shares; it would secm to indicate that if a dividend to the amount of the preference for a given year is in fact not declared to such non-cumulative shares, the right to receive this amount of dividends in priority to dividends upon the common shares is gone forever, whether or not funds were lawfully available for the unpaid preferred dividend, had management elected to distribute them. No case has squarely adopted this extreme connotation of the term "non-cumulative". Some have rejected it, while others have to a limited extent approved it.

When shares, described by the parties as preferred but noncumulative as to dividends, are created, whatever else they may have had in mind, it is incredible that either the offering party or the accepting party intended that if the corporation thereafter experienced in each of an unbroken number of years a profit more than enough to pay the amount of the preferred dividends, all of these profits might lawfully be paid to the holders of the common shares. And yet this is precisely what may happen if the term "non-cumulative" is accepted as the complete negation of "cumulative". Corporation X at its inception creates at par 1,000 common shares of $\$ 100$ par value each. Some years later Corporation $\mathrm{X}$ creates at par I,000 shares of $\$ 100$ par value each, entitling the holders to a non-cumulative preference as to dividends of $\$ 6$ per share. For each of the five years thereafter the net earnings of the corporation are $\$ 12,000$, but management elects to declare no dividends curing this period. During the sixth year the earnings are also $\$ 12,000$ and at the end of that year, management declares a dividend of $\$ 6$ per share on the preferred and $\$ 66$ per share on the common. When the preferred protest, they are informed by management that they have no ground for complaint since they are receiving the amount of their dividend preference for the current year, and all claims to dividends for the preceding years are gone forever since no dividends were declared and their shares are "non-cumulative". If this be a legally correct response, then the law has left open a tremendous loophole through which management can favor one class of shareholders at the expense of another.

The most thoroughgoing consideration of the respective rights of non-cumulative preferred shares and of common shares to dividend dis-

35. Bank of America Nat'l Trust \& Savings Ass'n v. West End Chemical Co., 37 Cal. App. (2d) 685, 100 P. (2d) 318 (1940); Allied Mragnet Wire Corp. v. Tuttle, 199 Ind. 166, 154 N. E. 480 (1926); Lockwood v. General Abrasive Co., 210 App. Div. I4I, 143,205 N. Y. Supp. 5 II (1924); II FLETCHER, op. cit. sipro n. 5 at 777 ; STEvews, op. cit. supra n. 5 at 410 . 
tributions is to be found in a series of decisions by the New Jersey judiciary. In successive cases involving the shareholders of the United States Cast Iron Pipe \& Foundry Co., the court held: ( 1 ) that in a year in which there were no current net earnings out of which current dividend preferences might be paid, management was entitled to pay from surplus a dividend to the holders of non-cumulative preferred shares to an amount equal to net earnings which might have been distributed to them in prior years $;^{30}$ (2) that management might in a given year pay to the non-cumulative, non-participating preferred shareholders, in addition to the amount of their preference for that year, an amount representing earned but unpaid dividends on their shares for $\mathbf{a}$ preceding year; ${ }^{37}$ and ( 3 ) that even when the non-cumulative preferred have received the amount of their preference from the net earnings of a given year, management may not pay a dividend to the common shareholders out of the remaining net earnings for the same year, while amounts equal to earned dividends from prior years remain unpaid on the non-cumulative preferred shares. ${ }^{38}$ In two subsequent cases, ${ }^{30}$ however, it has been held that a non-cumulative preferred shareholder may not restrain the distribution to junior shareholders of an amount equal to surplus earned in previous years during which dividends might have been, but were not, declared or paid upon the non-cumulative preferred shares.

The judicial opinions dealing with these controversies between holders of non-cumulative preferred shares and holders of common or other junior shares over the current distribution of sums equivalent to prior net earnings often seek support for their diverse rulings in some particular fact such as whether or not the past net earnings had been utilized by the corporation for "permanent improvements", 40 or whether or not the directors held substantial blocks of the junior shares. ${ }^{41}$ But

36. Bassett v. U. S. Cast Iron Pipe \& Foundry Co., 75 N. J. Eq. 539, 73 Atl 514 (1909); accord, Collins v. Portland Electric Power Co., I2 F. (2d) 67I (C. C A. 9th, 1926). For an extensive analysis of the New Jersey decisions and kindred "dividend credit" problems, see BerLe, Studies in the LAw Of CoRporation Finasce (ig28) chs. $\mathrm{V}$ and $\mathrm{VI}$.

37. Mforan v. U. S. Cast Iron Pipe \& Foundry Co., 95 N. J. Eq. 388, 123 Atl. 546 (I924), aff'd, 96 N. J. Eq. 698 , I26 Atl. 329 (I924); accord, Wood v. Gary, 47 Hun 550 (N. Y. I888), aff'd, 124 N. Y. 83,26 N. E. 338.

38. Day v. U.'S. Cast Iron Pipe \& Foundry Co., 96 N. J. Eq. 736, 126 At1. 302 (1924). Contra: Norwich Water Co. v. Southern R. R., II VA. L. REG. 203 (Richmond City Ct. I925).

39. Wabash Ry. Co. v. Barclay, 280 U. S. Ig7 (1930), rec'g, Barclay v. Wabash Ry. Co., 30 F. (2d) 260 (C. C. A. 2d, I929); Joslin v. Boston \& Ifaine Ry., 274 lfass. 55I, 175 N. E. 156 (1931).

40. See Mr. Justice Holmes' opinion in Wabash Ry. Co. v. Barclay, 280 U. S. 197 (1930). and the dissenting opinion of Judge Hand in Barclay v. Wabash Ry. Co, 30 F. (2d) 260,267 (C. C. A. 2d, 1929).

41. Although Mir. Justice Holmes' opinion in the Wabash case was astonishingly bricf, he did take occasion to mention that "the control of the Wabash seems to have been in Class A, the class to which the plaintifís belong. . . ." $280 \mathrm{U}$. S. 197, 203
(1930). 
such considerations are of little relevance. Will a right of the preferred shareholders be violated by the proposed dividend payment to the common shareholders? This is the primary issue. Such a right, if it exists, is violated not when the directors elect to transform funds available for dividends on the preferred shares into fixed or other assets, but when the directors subsequently determine that the interests of the corporation do now warrant a dividend to the common shareholders. And if such a right exists, the detriment to the preferred shareholders from its violation will be just as great whether the directors act in good faith or not. The particular language of applicable statutes or provisions of the articles of incorporation is also stressed by the opinions in these cases. But the controversies arise for the very reason that the language of neither the statute nor the charter is explicit. The pretense that the words used require one rather than another of disputed interpretations tends to conceal the principle or policy which really underlies the selection of the "interpretation" adopted.

The majority opinion of the Circuit Court of Appeals in the case of Barclay v, Wabash Railway Co., ${ }^{42}$ while recognizing that the directors have almost absolute discretion as to when earnings shall be distributed as dividends, suggested that nevertheless the non-cumulative preferred shareholders acquired a "dividend credit" 43 in the annual undistributed earnings up to the amount of their preference. This concept affects not when earnings shall be distributed, but to whom, once a decision has been reached to distribute them. The majority of commentators upon the non-cumulative dividend cases have approved the underlying theory of the Circuit Court in the Wabash case."4 Is it possible that herein is to be found a principle of general application to all controversies between classes of shareholders over dividend distributions, of which the non-cumulative cases are but a specific application? Should the rights of shareholders of whatever class to a declared dividend be determined by reference to their respective, rights to an amount equal to the fund about to be distributed, if dividends of all the earnings of the corporation had been declared at the end of each fiscal period in which earned? Is such a dividend credit theory feasible? To what extent is it supported by the decided cases?

Before proceeding with a further consideration of these questions, some preliminary matters should be clarified. In the first place, although

42. Note 39 supra.

43. "Preferred A stock received a dividend credit to the extent of the earnings each year, not to exceed 5 per cent. It sccured no dividend credit whatever in any year where there were no earnings." Barclay v. Wabash Ry. Co., $30 \mathrm{~F}$. (2d) 260,262 (C. C. A. 2d, 1929).

44. See, e. g., BerLe, op. cit. sipra note 36 , at 92-110; Hicks, The Rights of NonCumulatice Prcferred Stock-A Doubtful Decision of the U. S. Suprcme Court (193I) 5 Texp. L. Q. 538; Lattin, Is Non-Cumulatiz'e Preferred Stock in Fact Preferred? (1930) 25 ILL. L. REv. I48. 
a corporation must have profits or net earnings in order to be in a position law fully to declare a cash dividend, such profits or net earnings need not exist among its assets in the form of cash. For example, a corporation may, have a surplus of say $\$ 50,000$ without having any cash. If it desires to pay a cash dividend of $\$ 50,000$, it may acquire the necessary funds either by selling assets of that value or by borrowing such a sum. In the latter event the corporation's assets and liabilities will each be increased by a like amount, the amount of the surplus will consequently remain unchanged, and the borrowed cash will be available for dividend purposes. Therefore, the fact that the corporation may have accumulated its past profits or net earnings in the form of fixed or current assets other than cash should have no bearing upon the respective rights of shareholders to cash dividends subsequently declared.

Furthermore, it is faulty to conceive of a given dividend declaration as being a proposed distribution of the profits of a particular fiscal period. If the directors purport to declare at the end of 1940 a dividend of the profits of $1938,{ }^{45}$ they are in fact merely stating that they now propose to reduce the assets of the corporation by distributing to the shareholders an amount equal to the $193^{8}$ profits. The $193^{8}$ profits have become merged in the general assets of the corporation and are in no way segregated or ear-marked. The rights of shareholders of various classes may be contingent on the fact that there were undistributed net earnings in a given year, but the respective rights of the shareholders whenever a dividend is thereafter declared will not be affected by the fact that the directors measure the amount of such dividend by reference to the net earnings of a designated year.

Thus far the application of the principle of dividend credit has been related only to non-cumulative preferred shares. The extent to which this principle is relevant not only to such shares but also to common shares as well as other types of preferred shares may best be indicated by a series of illustrative cases.

Illustration I. At its inception Corporation $C$ issues 1,000 common shares and $1,0006 \%$ non-cumulative preferred shares, all of a par value of $\$ 100$ each. At the end of the first year of its existence Corporation $C$ has no funds lawfully available for dividends. At the end of its second year Corporation $C$ has $\$ 12.000$ lawfully available for dividends. ${ }^{48}$ There having been no profits or earnings during the

45. For an illustration of such a dividend declaration see Collins v. Portland Electric Co., 12 F. (2d) 671 (C. C. A. gth, 1926).

46. Some jurisdictions permit dividends to be paid from the net earnings of each fiscal year even though there may be a continuing capital impairment; most states limit dividends to surplus and thus properly forbid distributions to shareholders if a deficit exists or would be caused thereby. 
first year, the holders of the preferred shares have no right to dividends with respect to that year. If the directors determine to distribute the $\$ 12,000$ to the shareholders at the end of the second year, the holders of the non-cumulative preferred are entitled to $\$ 6$ per share first, and then the holders of the common are entitled to a like amount. The directors may validly determine to declare a $\$ 6$ dividend on the preferred and no dividend on the common. But if the board, purf riting to exercise its discretion, were to declare a dividend of $\$ 12$ per share on the preferred, i. e. $\$ 6$ for each year of its existence, the rights of the common would be violated, and the holders thereof could enjoin the dividend in excess of $\$ 6 . .^{47}$

If the directors declare a $\$ 6$ dividend on the preferred and no dividend on the common, the holders of the latter acquire a dividend credit of $\$ 6$ per share. This dividend credit must he naid before anv subsequent dividends may be received by the preferred. Consequently, if during the third year Corporation $C$ had net earnings of $\$ 6,000$, thereby increasing the undistributed profits to $\$ 12,000$, the common could nevertheless enjoin a dividend to the preferred for the third year until the dividend credit of $\$ 6$ per share on the common, resulting from the second year's undistributed earnings, had first been paid. If the dividend resolution of the directors specifically stated that they were distributing the $\$ 6,000$ earnings of the third year and not the $\$ 6,000$ of undistributed earnings of the second year, this fact would be completely. immaterial; the common would nevertheless be entitled to $\$ 6$ per share before the preferred received any further dividends.

If the directors declare no dividends at the end of the second year, the preferred and the common will each have a dividend credit of $\$ 6$ per share, but the preference of the preferred will still extend to this credit. Whenever the directors decide to pay a dividend, dividend credits must first be paid in accordance with their seniority in time. If the corporation should earn $\$ 6,000$ during the third year and declare no dividend at the end thereof, thus creating a further dividend credit on the preferred of $\$ 6$ per share, and if during the fourth year there should be neither profits nor losses, a dividend of $\$ 6,000$ at the end of the fourth year should go exclusively to the preferred in payment of their preferred dividend credit for the second year. Any further dividend up to $\$ 6,000$ should be paid to the common on account of their dividend credit for the second year, before the dividend credit of the preferred for the third year is paid.

Upon a transfer of shares all dividend credits pass from the transferor to the transferee. If a dividend declaration creates a debt of the

47. Collins v. Portland Electric Power Co., 12 F. (2d) 67I (C. C. A. 9th, 1926); 12 FLETCEER, op. cit. supra note 5 , at 189 
corporation to a class of shareholders to whom a dividend credit is due, the then holders of such shares are entitled to the declared dividend, and upon a subsequent transfer of the shares the dividend credit passing to the transferee is correspondingly reduced.

If the directors declare a dividend on the common in violation of a prior claim of the preferred, or vice versa, the declaration does not have the effect of creating a duty in the corporation to pay a dividend to the shareholders having the prior claim, as the declaration did not designate them as the recipients of the dividend and they would not be justified in relying thereon.

If Corporation $C$ earns $\$ 6,000$ during its first year but declares no dividends, and earns another $\$ 6,000$ during its second year, the directors may declare a dividend of \$1 2 per share on the non-cumulative preferred at the end of the second year, ${ }^{48}$ although the dividend preference of the preferred for a single year is only $\$ 6$ per share. The directors may (although they cannot be compelled to do so) pay a single dividend of a greater amount to the preferred if a dividend credit on such shares justifies the additional dividend and the funds are lawfully available.

Illustration 2. At its inception Corporation C issues 1,000 common shares and $1,0006 \%$ participating preferred shares, all of a par value of $\$ 100$ each. At the end of the first year of its existence Corporation $C$ has net earnings of $\$ 14,000$ and the directors pay a dividend of $\$ 6$ per share on the preferred and $\$ 6$ per share on the common. Since the preferred are participating, the preferred and the common each have a dividend credit of $\$ 1$ per share in the remaining $\$ 2,000.49$ The preferred and the common are on a parity with respect to this credit as the preference of the preferred extends only to the designated amount and not to further dividend participation in excess thereof. If the corporation earns $\$ 10,000$ during the second year, and at the end thereof the directors declare a dividend of $\$ 6$ on each share, preferred and common, the preferred could enjoin all but $\$ I$ of this dividend to the common. If the directors desire to pay any dividends at the end of the second year, they should first pay $\$$ I per share to both the common and the preferred in satisfaction of the dividend credit of the first year; then any further dividends should be paid to the preferred up to $\$ 6$ per share. This would clear up the dividend credit on the preferred and leave a balance of $\$ 4,000$ as to which the common would have a dividend credit of $\$ 4$ per share.

If the corporation had earned only $\$ 4,000$ during the second year and at the end thereof the directors had declared a dividend of $\$ 6$ per

48. Note 35 supra.

49. See BERLE, op. cit. supro note 36 , at $111-130$. 
share on the preferred, the common could have enjoined the entire dividend. If the directors desire to distribute the entire $\$ 6,000$ of surplus, they should pay $\$$ I per share to the preferred and to the common, and then $\$ 4$ per share to the preferred, leaving the preferred with a dividend right of $\$ 2$ per share if cumulative, and no dividend credit if not. cumulative.

If the preferred shares had been non-participating, the common would have had a dividend credit of $\$ 2$ per share in the $\$ 2,000$ of net earnings remaining after the six percent dividend. This amount might validly be paid to the common at any time thereafter from any funds law fully available for dividends. For example, if after two months of the second year had elapsed the directors were to declare a $\$ 2$ dividend on the common, the rights of the preferred would not be violated, despite the fact that they had not received the amount of their dividend preference for the year in which this dividend to the common was paid. ${ }^{50}$

Illustration 3. At its inception Corporation $C$ issues 1,000 common shares and $1,0006 \%$ cumulative preferred shares, all of a par value of \$100 each. At the end of the first year of its existence Corporation $C$ has net earnings of $\$ 12,000$ and the directors pay a dividend of $\$ 6$ per share on the preferred, leaving the common with a dividend credit of $\$ 6$ per share in the remaining $\$ 6,000$ of net earnings. During the second year the corporation has neither profits nor losses. During the third year the net earnings are $\$ 12,000$. If at the end of the third year the directors should declare a dividend of \$12 per share on the preferred, the common could enjoin the entire dividend, despite the iact that the preferred are cumulative. If the directors desire to pay any dividends, they must wipe out the dividend credit of $\$ 6$ per share on the common since this arose prior to the accumulated back dividends on the preferred. A payment at the end of the second year of a $\$ 6$ dividend on the cumulative preferred would also have been subject to injunction by the common. The cumulative feature of the preferred applies only to future earnings and does not alter the rights of other shareholders which have already accrued as a result of prior undistributed earnings.

At the end of the third year Corporation C's surplus is $\$ 18,000$. Accumulated earned surplus is a unitary concept, a single bookkeeping item. It does not consist of separate funds representing the undistributed net earnings of various past years; it is merely a figure representing the total amount lawfully available for dividends to the shareholders. The only significance of the figures indicating the net earm-

50. Continental Ins. Co. v. Minneapolis, etc., R. R., 283 Fed 276 (D. Minn. I922), $a f f^{\prime}, 290$ Fed. 8 ; (C. C. A. 8th, 1923). 
ings for individual years is to establish the proportionate rights of shareholders to such distributions as the corporation may legitimately decide to make to them. Such distributions all come from a single source, namely, the assets of the corporation at the time of the distribution. Consequently, if Corporation $\mathrm{C}$ determines to distribute its surplus of $\$ 18,000$ to its shareholders, the fact that $\$ 12,000$ was earned during the third year is not material. The significant facts are, in this order, that $\$ 6$ per share might have been paid to the common at the end of the first year and was not, that the cumulative preferred received no dividends for the second year, and that they have as yet received no dividends for the third year. The common now have the senior dividend credit; after they have received $\$ 6$ per share, they will not be entitled to any further dividends, regardless of the extensiveness of the corporation's future earnings, until the preferred have received $\$ 12$ pei share, as the dividend right of the preferred will have become the senior one.

Illustration 4. At its inception Corporation C issues 1,000 common shares and $r, 0006 \%$ non-cumulative preferred shares, all of a par value of $\$ 100$ each. At the end of the first year of its existence Corporation $C$ has net earnings of $\$ 6,000$, but the directors declare no dividends. During the second year Corporation $\mathrm{C}$ suffers an operating loss of $\$ 6,000$. At the end of the third year the corporation has net earnings of $\$ 12,000$. If the directors were to declare a dividend of $\$ 6$ per share on the preferred and $\$ 6$ per share on the common, the preferred could enjoin the entire dividend on the common. The undistributed earnings of the first year created a dividend credit of $\$ 6$ per share in favor of the non-cumulative preferred. The loss of the second year eliminated the fund lawfully available for dividends, but did not wipe out the dividend credit. The net earnings of the third year added another $\$ 6$ per share to the dividend credit of the preferred. Hence the preferred are entitled to receive $\$ 12$ per share before any dividends are paid to the common.

If the net earnings of the first year had been $\$ 12,000$, there would have been a dividend credit of $\$ 6$ per share on the common as well as on the preferred. If the corporation then lost $\$ 24.000$ during the second year, this would wipe out the surplus available for dividends and create a deficit (or capital impairment) of $\$ 12,000$; but the dividend credits of both common and preferred would remain. Now if the corporation were to have an excess of income over expenses, i. e. net earnings, of $\$ 6,000$ during the third year, this would reduce the deficit to $\$ 6, \infty 00$, but would not add to the dividend credit of the preferred, for it is not a fund which might be utilized for the current year's dividends in jurisdictions which prohibit dividend payments except out of sur- 
plus. Even in jurisdictions which by statute permit current net earnings to be distributed as dividends despite prior capital impairment, the $\$ 6,00$ of net earnings in the third year would not increase the dividend credit of the preferred; this sum, if distributed, would be completely used up by the claims of the existing dividend credits, and therefore the distribution of these profits would not in fact result in the preferred receiving any more dividends than they were already entitled to. In short, additional dividend credits arise only when funds available for dividends, to which the shareholders are not already entitled, are withheld from them by the directors. For example, if Corporation $C$ had suffered an operating loss of $\$ 12,000$ during its first year, and had had net earnings of $\$ 6,000$ during the second year, the preferred would acquire a dividend credit of $\$ 6$ per share in jurisdictions permitting current net earnings to be utilized for dividend purposes regardless of past losses; this is because, if the directors were to distribute this $\$ 6,000$, it would go to the preferred not in reduction of a dividend credit but by virtue of a current priority to this extent over the common. In other jurisdictions, having the normal common law rule that dividends may be paid only out of surplus, the non-cumulative preferred would acquire no dividend credit. It may be objected that this latter result puts the entire loss in the long run upon the preferred and not on the common, but to the present writer it seems a reasonable conclusion that the parties did not intend any claim to dividends to accrue to the non-cumulative preferred in the absence of any funds which might lawfully be distributed as dividends.

Some might contend that if Corporation $C$ had had net earnings of $\$ 12,000$ the first year, and a loss of $\$ 6,000$ the second year, the effect of the loss would be to wipe out the dividend credit on the common, thereby throwing the entire loss on the junior shares. ${ }^{51}$ This is, of course, a possible result, but it is wholly inconsistent with the theory that once a dividend credit (even on common shares) has developed, it is senior to any dividend claim that may thereafter accrue to any class of shares, preferred or common, just as, when earnings have been validly distributed to the common, the right to retain such dividends is unaffected by any subsequent dividend claims that may arise.

If the shares outstanding are cumulative or participating preferred, the basis for the allocation of losses is the same as that already set forth. A dividend right regularly accrues to cumulative preferred shares regardless of earnings, whereas dividend credits on common or noncumulative preferred or participating preferred are always the resultant of undistributed net earnings (there may, as previously indicated, be

51. See BERLE, op. cit. supra note 36, at 101-103, 124-130. 
priorities among the various holders of dividend claims); but once any dividend claim has arisen, it is a claim against future dividends that can be discharged only by payment. Losses affect only the size of the fund available for dividends and do not alter the previously established rights of the various shareholders among themselves whenever dividends are distributed. For example, suppose Corporation $C$ to have outstanding $I, 000$ common shares and $I, 000 \$ 6$ cumulative preferred shares which further entitle the holders, after the common have also received $\$ 6$ per share from the net earnings of a given year, to a dividend participation of $\$ 2$ per share, after which any balance of said net earnings are payable to the common. If at the end of the first year Corporation $C$ has net earnings of $\$ 17,000$, there would arise first a dividend credit of $\$ 6$ on each preferred share, then a dividend credit of $\$ 6$ on each common share, next a dividend credit of $\$ 2$ on each preferred share, and finally a dividend credit of $\$ 3$ on each common share. These dividend credits must be paid, in this order, before any other dividends are distributed. If the corporation should lose $\$ 6,000$ during the second year, the only effect would be to reduce the funds available for dividends to $\$ 11,000$. If the third year produced net earnings of $\$ 4,000$ and the directors should decide to distribute to the shareholders the resulting surplus of $\$ 15,000, \$ 8$ per share ( $\$ 6$ plus $\$ 2$ ) should go to each preferred share, and $\$ 7$ per share ( $\$ 6$ plus $\$ 1$ ) to each common, leaving the common with a dividend credit from the first year of $\$ 2$ per share, and the preferred, because they are cumulative, with a dividend right of $\$ 12$ for the second and third years. These dividend claims should be honored in this order in the event of any subsequent dividend payments.

Furthermore, a corporation, unless legally obligated to do so, ought not to make any distributions other than dividends to its shareholders while dividend claims are unpaid. If the articles stipulate that a class of shares is subject to redemption or entitled to a capital preference on dissolution, such rights will take priority over dividend claims. But a corporation ought not voluntarily to distribute corporate assets to shareholders, e. g. by purchasing shares, in disregard of its shareholders' dividend claims. This means, as the English courts have held, ${ }^{52}$ that a corporation should never deliberately purchase its own shares, since such purchases must be limited to surplus, and undistributed surplus cannot arise without dividend credits also resulting. Indeed, a pernicious corporate practice that has flourished especially during depression years is the use of corporate assets to buy in even cumulative preferred shares at depressed prices brought about by management withholding

52. Trevor v. Whitworth, 12 App. Cas. 409 (1887). 
dividends on these very shares. This may redound to the eventual benefit of the common shareholders, whose equity in the enterprise may be thereby enhanced, but the unfairness to the shareholders who are caused by this manipulation to sacrifice not only dividends but also market value is manifest. Consistent adherence to the dividend credit principle would preclude such injustice.

\section{Theory and Practice}

The foregoing discussion reveals that the theory of dividend credit is not limited to cumulative and non-cumulative preferred shares. Logically it applies as well to the rights of participating preferred and even common shares to partake in the distribution of profits after fixed dividend preferences have been paid. Yet the cases applying this doctrine, which thus far have reached courts of record, have been confined almost exclusively to the rights of non-cumulative preferred shareholders. Some of the reasons for this are readily understandable.

The dividend priorities of cumulative shares are too well established to be the subject of litigation. Moreover, where junior (e. g. common) shares have dividend credits in past undistributed earnings, they are not likely to assert them against cumulative preferred shares; current dividends on such preferred shares, not paid now out of present or past earnings, will have to be paid anyway in the future before the junior shares can participate in subsequent earnings, and the "bird in the hand" idea has apparently not been a sufficient incentive to induce the holders of junior shares to risk the expense of a lawsuit in vindication of their dividend credits.

Conversely, it was to be expected that litigation would be provoked by the declaration of dividends upon common shares while past earned dividends upon non-cumulative preferred shares remained unpaid. After all, the non-cumulative shares are preferred as to dividends, and the preference becomes largely illusory, if corporate earnings may in this fashion be diverted from the preferred to the common.

But the real mystery is that those shareholders, whose rights in corporate profits are not limited by fixed preferences, have not more often challenged dividend declarations that violate the principle of dividend credit. If the principle of dividend credit is not adhered to, the directors may divert earnings from participating preferred shares to common shares, or vice versa. Moreover, the directors are also in a position to shift the burden of losses; occurring after the accumulation of a surplus, from one group of dividend participants to another. Furthermore, on dissolution of a corporation having an accumulated surplus, grave injustice may result to one class or another, if principles of 
dividend credit are ignored. ${ }^{53}$ The only explanation for the paucity of decisions in this field would seem to be that shareholders and their advisers have not sufficiently realized that the discretion of directors as to when profits shall be distributed need not include discretion as to who shall receive the profits when distributed.

No doubt there will be those who will maintain that however excellent the dividend credit rule may be in theory, it is utterly unworkable in practice. The objection is principally that in the case of a corporation with a large but fluctuating income and a complicated share structure, it would be too difficult, first, to calculate and, secondly, to keep track of the amount of undistributed profits to which each class of shares is annually and in the aggregate entitled. But every corporation now, for tax and other purposes, has to attempt to figure its annual net earnings to the very penny, and for any single year it is a comparatively simple arithmetical problem to determine how much of the net earnings will go to each share outstanding at the end of the year, if the entire net earnings for that fiscal period are to be distributed. Actually, it is very little more difficult for a corporation to aggregate odd amounts that would develop to the credit of various classes of shares under this principle as a result of not distributing net earnings, ${ }^{54}$ than it is to cumulate fixed sums regardless of earnings as in the case of cumulative preferred shares. At the end of each year the corporation could notify each shareholder, as is frequently done in the case of insurance companies, of the amount of undistributed surplus to the credit of his shares for the year and in the aggregate.

Finally, it should be noted that, whatever the drawbacks of the dividend credit principle from management's standpoint, they are more than offset by two great advantages to the shareholder. First, the widespread acceptance of this principle should result in a more liberal dividend policy on the part of many corporations, as the possibility of favoring one class of shareholders at the expense of another would no longer provide an incentive for delay in distributing corporate profits. Corporate shares are becoming less and less attractive as a form of investment. Management, labor, and even the consumer have reaped the benefits of large-scale production made possible by the corporate device, while the shareholder has been increasingly neglected. ${ }^{\text {s5 }}$ The arrogant practices of many corporate officers are in some measure responsible for this development. The enforcement of the dividend credit principle could be an important means of establishing in the shareholder a sense

53. KeHL, Corporate Dindends (1941) 192, 193.

54. A similar accounting problem is involved in determining the annual amount to which each holder of an income bond is entitled. 424.

55. Fleming, Are Stockholders Peoplel, Harper's MAgnzine (March, 194I) 422, 
of greater security and of again arousing in him the active interest of a proprietor.

Secondly, one of the long-term advantages of the dividend credit principle is that it would probably induce a gradual simplification of share structures. An objection sometimes offered to the dividend credit principle is that, whenever a dividend is paid, there will result disputes and litigation among the shareholders and with the corporation as to whether the appropriate amount has been paid to the proper persons. If this be true (and to the present writer it does not seem inevitable), the explanation probably lies in the unnecessarily complicated share structures which so many corporations have developed. Many of the financial ills of the late twenties and early thirties were a concomitant of the absurd variety of different types of securities which were invented by corporate managers or promoters either to beguile the unwary investor or to provide trading ammunition upon corporate reorganizations where an effort was made to mollify various groups with divergent claims. A rigid limitation of corporate securities to say three types would be a salutary development; these might bolixed interest first mortgage bonds, ciumulative non-participating preferred shares and common shares. Admittedly this would inject an element of rigidity not now present in corporate financing, but the advantages to the investor would more than offset the loss of flexibility which management would experience. Such a requirement would simplify the application of the dividend credit rule, and would eliminate most of the uncertainties which at the present time are the major source of conflicts between shareholders and management concerning dividends. 